\title{
IMPROVING THE MARKETING STRATEGY INTO 7PS+ FOR SUSTAINABILITY: A STUDY OF BALI TOURISM, INDONESIA
}

\author{
Iswara Agus Made Yoga*, Budiarsa Made, Ardika I Wayan, \\ Wiranatha A.A.P. Agung Suryawan \\ Faculty of Tourism, University of Udayana, Bali, Indonesia \\ *E-mail: agus.iswara@hotmail.com
}

\begin{abstract}
This article discusses the strategic role of the sales and marketing team in the accommodation business in achieving sustainable tourism development in Bali. The aim is to find ideal sales and marketing practices that can contribute to sustainable tourism development in the tourism industry in Bali. This research was conducted using qualitative approach. Data collection methods in this study were literature, observation, depth interviews, and Focus Group Discussion. Expert determinations in this research are the represent of government, tourism industry, private parties, academics, and society by using a purposive sampling technique. The results of this study show 3 existing models of marketing components of the tourism industry in Bali, namely the profit direct-oriented model, the profit indirect-oriented model, and the profit mix-oriented model. There are positive and negative impacts of a profit-oriented marketing model. Marketing Mix 7P for Sustainability or Marketing Mix 7P + is a combination of 7P in the marketing mix and elements of the triple bottom line theory. The conclusion is that the accommodation service industry in Bali mostly operates a profit-oriented marketing model; an innovative marketing model is present as a response to the negative impacts caused by the marketing model currently applied by most types of accommodation business in Bali which is more focused on achieving economic aspects.
\end{abstract}

\section{KEY WORDS}

Marketing mix, tourism, innovation.

The sales and marketing team are the spearheads in gaining market share and hotel business profits in the tourism industry sector. However, their existence has never been given the responsibility of participating in realizing sustainable tourism. This article discusses the strategic role of the sales and marketing team in the accommodation business to participate in realizing sustainable tourism development in Bali, Indonesia. The aim is to find ideal sales and marketing practices that can contribute to sustainable tourism development. This study is urgent because, through contact with prospective customers and travel agents or wholesalers, sellers and marketers not only sell their business packages but also provide education to prospective customers about sensitive matters in Bali and those related to efforts to realize sustainable tourism.

The development of ideal tourism has a concept that can minimize negative impacts and not burden the next generation. At least, this is the fact before the Covid-19 pandemic immediately halted various businesses including the tourism industry. Sustainable tourism destinations, of course, also require a form of sustainable marketing (Jauhari ed. 2014). It is undeniable that the tourism industry is vulnerable to trials such as natural disasters, security disturbances, and outbreaks so that it quickly collapses, but time proves that the recovery process is very fast, faster than anyone imagined, as Bali has experienced after terrorism and epidemic attacks bird flu some time ago (Gurtner 2016; Hitchcock and Son 2007).

That recovery experience is a great hope that as soon as the Covid-19 problem can be solved globally, all life activities including tourism can quickly return to normal or go to a new normal better than before. The core of the concept of sustainable tourism is the integration of economic aspects, social aspects, and environmental aspects in each of the strategic tourism activities (Putra and Paturusi 2017; Rahmawati et. Al 2018). Tourism that takes full 
account of current and future economic, social and environmental impacts, responds to the needs of visitors, the tourism industry, the environment, and the host community.

But in reality, the concept of sales is still oriented towards large profits but is not concerned with customer satisfaction, while the marketing concept is more oriented to profits and also concerned with customer satisfaction, loyalty, and repurchase. The concept of sales and marketing concepts now only dominates the economic aspect, which is to maintain survival to grow, increase loyalty and earn profits, while the environmental and social aspects of sustainability are only complementary if the economic aspects have been met.

Likewise with the phenomenon of corporate social responsibility or known as CSR (corporate social responsibility), one of the goals of a company to run CSR is to gain positive legitimacy from the market, the government, and surrounding communities (Rahmawati 2018; Haniffa and Cooke, 2005). Ironically the CSR allocation is under the GOP (gross operating profit), which means that companies can only think of social and environmental aspects if they succeed in achieving the expected benefits. Jamrozy (2007) states that when alternative approaches to tourism marketing include social considerations such as the impact of tourism and environment-based segmentation strategies, then three fundamental aspects become tourism destinations to be more sustainable by adopting an integrated tourism marketing perspective.

During this time, the role of marketing is rarely taken into account in the context of the discussion of sustainable tourism development. This happens because marketing is still understood narrowly as an attempt to get as many tourists as possible, separately to increase market share. Professionals also assume that their main task is to sell products, while the task of preparing products for sale is the task of another party or person. If examined deeper, the role of marketers is not only selling products but is responsible for making and maintaining product quality.

If seen in macro point of view, in order to achive quality and sustainability, the marketers should participate in making the products, including the tourist destinations itself. Marketing can not only meet the expectations and desires of tourists just to get profits and satisfy tourists, with social, cultural, and environmental costs borne by the people at the destination. In addition, professional marketing ideally should be able to negotiate with customers to invite customers to participate in preserving the natural and cultural destinations they visit (Bramwell et. al 2009).

\section{LITERATURE REVIEW}

Research on the problems of sustainable tourism development in Indonesia in general and in Bali are always associated with examining the benefits of tourism in environmental preservation, the benefits of tourism in providing economic benefits, and preserving sociocultural development (Rahmawati et. Al. 2018; Bendesa and Aksari 2017; Putra and Paturusi 2017). Tourism is an activity that directly touches and involves the community so that it brings various impacts on the local community.

The impact of tourism in the area of study that receives the most attention in the literature, especially the impact on local communities (Pitana 2005). Ardika (2007) states that sustainable development implies a limit determined by technology and community organizations and by the ability of the earth's life to absorb the effects of human activities.

Pomering, et al (2010) in Tasmania, who combined marketing mix strategies with sustainable models. This research was conducted because of the contemporary marketing mix strategy of 4 Ps, 7 Ps and 8 Ps which apparently cannot answer the challenges of marketing sustainability issues, so it is necessary to innovate by combining with the three elements of the Triple bottom line namely; people, planet and profit. Triple bottom line theory is a thought about sustainable business that put the sustainability of nature (planet) as a source of all resources, the welfare of the people and obtain sufficient profits for the survival of the company (Jamrozy, 2007). 


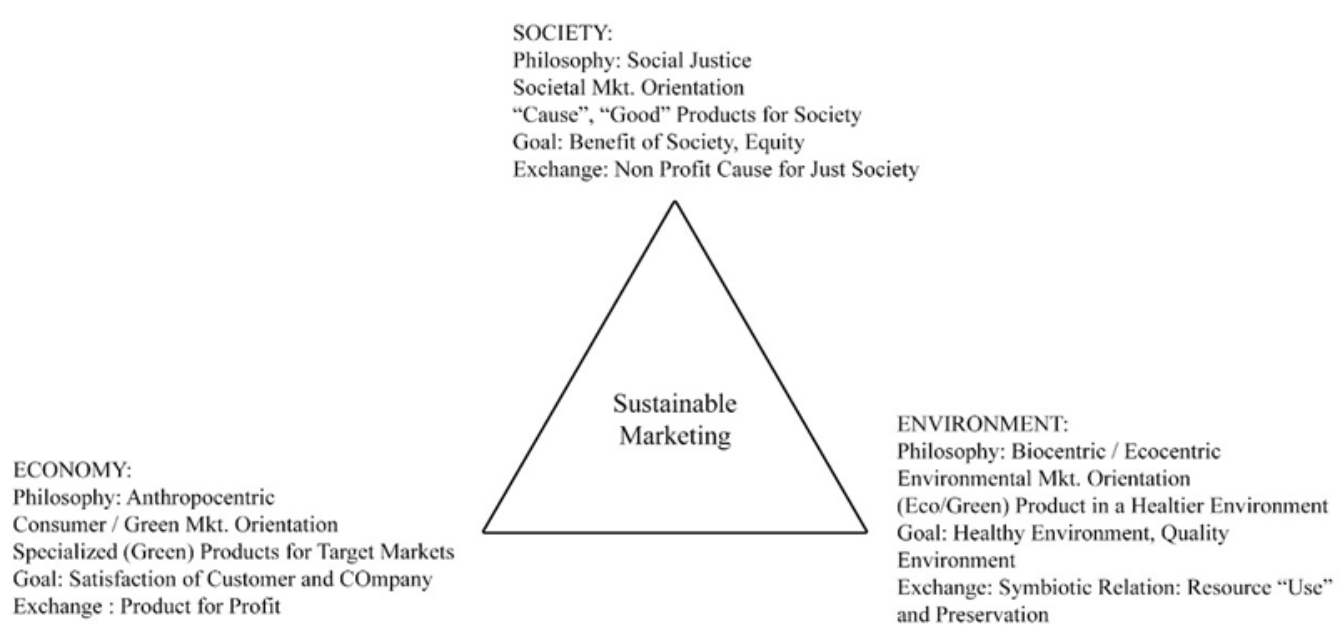

Figure 1 - Sustainable Marketing Model (Source: Jamrozy, 2007)

The triangular model (Figure 1) represents the three dimensions of sustainability, economic viability, social equity and environmental protection. The traditional consumeroriented marketing focus under the economic paradigm is inherently non-sustainable as it is solely focused on economic profit. The sustainable marketing approach integrates environmental, societal, and economic objectives (Jamrozy 2007).

Legitimacy theory is a social contract between a company and the community in which the company operates and uses economic resources (Ghozali \& Chariri 2007). The link between the theory of legitimacy in this research is that the practice and disclosure of social responsibility or the application of sustainable tourism marketing innovations will be considered as a way for companies to continue to align themselves with the norms in society. Thus, companies are advised to carry out sustainable marketing that has a positive impact on the environment, local communities, and the economy so that it provides positive benefits not only from economic aspects but also environmental and socio-cultural aspects, as well as gaining legitimacy for its business.

Stakeholder theory says that companies are not entities that only operate for their interests, but must provide benefits for stakeholders (shareholders, creditors, consumers, suppliers, government, society, analysts and other parties). Thus, the existence of a company is strongly influenced by the support given by stakeholders to the company (Ghozali \& Chariri, 2007). The first thing about stakeholder theory is that stakeholders are systems that are explicitly based on views about an organization and its environment, regarding the nature of mutual influence between the two that is complex and dynamic. The relationship of stakeholder theory in this study is that the successful application of sustainable tourism marketing innovations by a company is also very dependent on the support and understanding of stakeholders on the concept of sustainability.

Prior, et al. (2008) state that corporate social and environmental responsibility in annual reports can be used by managers as a tool to secure their position. This can occur because management has more information than other stakeholders as explained in the agency theory. The theory explains the existence of conflicts of interest between agents and principals. The principal is a shareholder or investor while an agent is a person authorized by the principal, namely management to manage a company consisting of a board of commissioners and a board of directors. The separation of ownership by the principal and control by the agent in an organization tends to cause agency conflict between the principal and the agent. According to Jensen and Meckling (1976) agency relationship is a relationship where the company owner (principle) entrusts the management of the company by others, namely the manager (agent) by the interests of the owner (principal) by delegating some decision-making authority to the manager (agent). 


\section{METHODS OF RESEARCH}

Tourism is an activity that directly touches and involves the community so that it brings various impacts on the local community. Over time, the concept of sustainable development was adopted into the concept of sustainable tourism development. This study was carried out with a qualitative approach. This research was in the form of descriptive research that was carefully measurement of certain social phenomena. The results of this study were describe or construct in-depth interviews and focus group discussions (FGD) on research subjects to provide a clear picture of understanding the innovations of sustainable tourism marketing models in Bali. This research was conducted in Bali, specifically in the type of accommodation business. Through the model of sustainability tourism marketing innovation, it was hoped that Bali would be able to improve itself in arranging Bali as a tourism destination that is cultured, quality, and sustainable. Data collection methods and techniques in this study were literature, observation, depth interviews, and FGD. Expert determination in this research were the represent of government, tourism industry, private parties, academics, and the public by using purposive sampling technique, the sampling technique was determined based on certain traits that were considered to have a relationship with research problems based on specific intensities within a group. This research used descriptive data analysis.

\section{RESULTS AND DISCUSSION}

Before the pandemic hit the world, the development of Bali's tourism was progressing rapidly in more than ten years. This is evidenced by various facts, such as the growth in the number of direct foreign tourist arrivals to Bali, growth in investment through property development related to tourism, which spread not only in Badung Regency, Denpasar but also in Gianyar, especially in the tourist area of Ubud (HVS 2015).

Daily Balinese life including traditional and religious based traditional activities is a unique attraction that Bali has that has proven to attract tourists (Vickers 2011; Picard 1996). Buleleng Regency in 2019 has the most tourist attractions, namely 86 locations, followed by Gianyar Regency which is 61 locations, Karangasem Regency which is 59 locations, and Bangli Regency which is 43 locations. Balinese people begin to recognize that the tourism sector is a mainstay sector that must be worked seriously so that the Balinese people not only become tourism stakeholders but can become tourism shareholders so that a joint effort is needed to realize it through the development of community based tourism (Akama and Kieti, 2007). Community based tourism (CBT) in Bali has become a positive phenomenon, where villagers have dared to appear to manage a tourist attraction such as Tanah Lot, Uluwatu, Monkey Forest, and Pandawa Beach.

In this study, there are 3 models of marketing for tourism industry component in Bali, namely the profit direct-oriented model, the profit indirect-oriented model, and the profit mix oriented model. The division was made based on existing data such as; marketing collateral, website, depth interview, and virtual guest comment by identification of prominent and similar characters so that they can be categorized into one group model. The first category of marketing models used in Bali referred to as the direct profit-oriented model, has salient characteristics in how communication is used to achieve profit. The second category is referred to as the indirect profit-oriented model, A marketing model in which the communication method does not explicitly focus on economic or profit aspects, but rather refines by emphasizing ethics. The third marketing model in this study is known as the profit mix oriented model, which is a way to communicate marketing that is similar to profit direct oriented, that has a strong characteristics and focuses on economic or profit aspects but is followed by a corporate social responsibility (CSR) program.

Entrepreneurs have a big responsibility in maintaining harmonious relations between social-cultural, economic, and environmental which are usually abbreviated with 3P: people, profit, planet. Every marketing model has advantages and disadvantages, strengths and weaknesses, or positive and negative impacts. The positive impact of the profit-oriented 
marketing model is (1) economic growth, (2) achievement of return on investment, (3) business continuity, and (4) increasing market share. While negative impacts are divided into two, namely (1) environmental impacts consisting of; land-use change, accommodation industry waste, plastic waste, and clean water crisis, and (2) socio-cultural impacts consisting of; cultural degradation, increased crime, hegemony towards residents, and congestion.

Innovative Marketing Model of Accommodation Business in Supporting Sustainable Tourism Development in Bali. Innovation is the keyword for progress. Progress does not only mean that changes from the situation for the better, but also provide benefits with as little negative impact as possible. The intended combination is not necessarily adding 7P to 3P, but applying the 7P marketing mix policy strategy to achieve 3P performance. This research is in the same direction and is a continuation of research from Pomering et al (2010) in Tasmania, which concludes that the contemporary marketing mix of 4P or 7P has not been able to answer the challenge of marketing sustainability issues. The limitation of Pomering et al's research is that it is only limited to proposals, whereas in this study the sample implementation phase has been reached. This innovation model results in a new marketing model called the 7P marketing mix for sustainability or in short is called the 7P + marketing mix or read Seven P Plus. The plus sign (+) is an indication of sustainability, so it can be said to be a sustainable marketing mix strategy that refers to the performance of 3P (profit, people, and the planet). Marketing Mix 7P for Sustainability or marketing mix 7P + (Seven P Plus) consists of the following.

Table 1 - Marketing Mix 7P+

\begin{tabular}{|l|l|l|}
\hline 1 & Product+ & $\begin{array}{l}\text { An item that satisfies the consumer's needs or wants. Products may be tangible (goods) or } \\
\text { intangible (services, ideas or experiences), and have considered the benefits of economic, } \\
\text { social, and environmental aspects }\end{array}$ \\
\hline 2 & Price+ & $\begin{array}{l}\text { The sacrifice consumers are prepared to make to acquire a product and have considered } \\
\text { the benefits of economic, social, and environmental aspects. }\end{array}$ \\
\hline 3 & Place+ & $\begin{array}{l}\text { Physical address (distribution Channel) of business where service professionals interact } \\
\text { with customers that have considered economic, social, and environmental benefits. }\end{array}$ \\
\hline 4 & Promotion+ & $\begin{array}{l}\text { The marketing communication used to make the offer known to potential customers and } \\
\text { persuade them to investigate it further, and has benefits of economic, social, and } \\
\text { environmental aspects. }\end{array}$ \\
\hline 5 & Participant+ & $\begin{array}{l}\text { Service personnel who represent the company's values to customers who have considered } \\
\text { the benefits from economic, social, and environmental aspects. }\end{array}$ \\
\hline 6 & $\begin{array}{l}\text { Physical } \\
\text { Evidence+ }\end{array}$ & $\begin{array}{l}\text { The physical evidence is a combination of the environment and branding where the service } \\
\text { is provided to a customer by a service representative, and have considered the benefits of } \\
\text { economic, social, and environmental aspects. }\end{array}$ \\
\hline 7 & Process+ & $\begin{array}{l}\text { The procedures, mechanisms and flow of activities by which service is delivered, and have } \\
\text { considered the benefits from economic, social, and environmental aspects. }\end{array}$ \\
\hline
\end{tabular}

Marketing Mix 7P for Sustainability or Marketing Mix 7P + is expected to be a solution for Bali marketers in carrying out their marketing strategies in meeting the economic targets set by the company and without neglecting social and environmental aspects, so that business sustainability can be achieved and at the same time the destination is also maintained its sustainability from environmental aspects and socio-cultural. Marketing Mix 7P + describes a marketing mix that is based on profit, people, and planet performance.

One example of tourism accommodation that has implemented the Product + strategy is the Five Elements Puri Ahimsa Retreat Bali, located in Mambal Abiansemal Badung, this company further emphasizes humanitarian missions, philosophy, harmony with nature, and local values in this matter Hinduism, like the explicit writing of the philosophy of Tri Hita Karana. The business vision was confirmed by writing explicitly: Our Vision: Learning to Love and Respect Life. Likewise, all the missions are written. From there it can be seen that it is not the tariff or price of the package that is emphasized but the cultural aspects, experience for tourists, and peace that is felt from nature, in other words, plus $(+)$ for product in marketing at Five Elements strongly oriented towards people as one element of the triple bottom line or overall spirit of Marketing Mix 7P +. 
One example of an accommodation business in Bali that applies Price + is Mana Earthly Paradise Resort, located in Ubud. This resort adopts the concept of traditional buildings combined with the concept of natural and modern style. The application of Price + component can be seen in the statement displayed on the website that the profit gained from customers will be used to support the Earth Company Foundation to support the changemaker movement in the Asia Pacific region.

Place + in sustainability marketing not only makes economic aspects as the only criterion but also considers the benefits of environmental and social aspects. Case study that applies the Place + marketing mix is Bagus Jati Health \& Wellbeing Retreat, which was built not in the heart of Ubud, but is located in Banjar Jati Sebatu Village, Taro, Tegallalang District, Gianyar Regency, which is approximately 20 minutes from the center of Ubud. The hotel location is in a plantation area that has views of the valley and river. If we observe, location selection is certainly not too strategic from an economic aspect, however the consideration is not to increase congestion in the center of Ubud, also refrain to build the hotel acomodation within the community settlements, so that the existence of these accommodation facilities do not have a direct negative impact, but instead can provide positive social benefits for the community and the surrounding environment.

One example of an accommodation business that applies for Promotion + is Griya Santrian a Beach Resort. Griya Santrian a Beach Resort is a local hotel brand that was first established in Sanur Bali. The resort first started operating in 1972. Carrying the slogan, where everyone is family, the resort developed a unique concept of hospitality namely life experience, which refers to the noble values of Balinese customs, culture, and various traditions. the message revealed that Griya Santrian paid attention not only to customers but also to think of benefits for employees and the community in the hotel environment, namely Sanur as a harmonious family relationship unit. Business slogans, in general, will convey business messages that focus on economic aspects, for example; slogans with quality products, competitive prices, or a combination of quality products and attractive prices. In this case, Griya Santrian has committed through its company slogan to maintain the sustainability of its destiny namely the Sanur area by maintaining harmonious relations between customers, employees and the local community of Sanur, one of the implementations is to absorb 75 percent of the local workforce from the Sanur community. This method of promotion may be less than optimal for the achievement of the economic aspect of profit, but the Promotion + model will provide an overview of the company of concern and responsibility for the sustainability of its destination while reducing social and environmental burdens that will be inherited in future generations.

Participants are the main assets in the service industry, especially businesses that require high-performance resources. In the sustainability marketing mix model, the Participants + component will encourage employees not only to have skills that focus on achieving profit, but also an understanding of how to create benefits for social and cultural aspects and the environment. One of the companies implementing participants + is Maca Group. In addition to being trained in upselling, cross-selling, handling difficult situations, Maca Group employees are also equipped with knowledge of environmentally friendly matters such as; restrictions on the use of disposable plastic materials, energy savings in villas, public areas and other operations, sorting organic and non-organic waste, waste treatment and other activities related to the surrounding population such as absorption of local fruit and vegetable products, supporting local businesses that located in the surrounding environment such as local laundry businesses, local businesses providing offerings, and local dance and drummer businesses that are used at events at hotels. This ability (knowledge) is important to be instilled in all employees (participants) so that every policy took always makes aspects of profit, people and planet as a reference in realizing sustainable concepts both for business and destination.

Physical Evidence + in the sustainable marketing mix model emphasizes not only economic aspects but also considers social and environmental aspects. Director of Sales of Five Elements Puri Ahimsa, Ketut Suenaradi said Puri Ahimsa offers the sensation of living in the wild, with a unique building design, and almost all physical form and interior using 
bamboo raw materials, other supporting facilities such as Restaurant, Wantilan for Yoga and Meditation, Gym, Spa and Wellness Center also adopt environmentally friendly buildings or referred to as Wellness Design \& Sustainability by adopting the local genius of Bali philosophy, Tri Hita Karana.

Process + ensures that the combined activities carried out to meet the profit, people, and planet performance. Process + becomes an important part of the sustainability marketing mix because each process carried out will strengthen the identity of the other marketing mix components, especially in applying sustainabability concepts that harmonize economic aspects, social aspects, and environmental aspects. Five Elements Puri Ahimsa Retreat Bali, in addition to implementing the Product + strategy, also includes business properties that also carry out a sustainable marketing mix through the Physical Evidence + and Process + strategies. The application of the Process + marketing mix can be seen from several programs that have been run, i.e: First, the application of site sensitivity and natural habitat during the hotel construction process by taking into account natural characteristics that exist during the design and construction process, complying with all local rules and culture, maintaining a minimum of $25 \%$ of land for reforestation and supporting all forms of sustainable transportation such as bicycle dipper, public transport and also electric car vehicles that do not have the impact of air pollution on the environment. Second, the use of clean water that meets international standards, especially in water conservation and recycling systems, using and empowering local water sources, collecting rainwater and recycling wastewater, and using equipment that can reduce the use of excessive water volumes. Third, energy management using high-quality but low-power LED lights, buildings and rooms are designed with design options to be able to use natural air and are not dependent on the use of air conditioners, and monitor the use of electricity regularly as well as make operational arrangements efficiently to avoid excessive electrical energy consumption. Fourth, the materials used in the hotel environment are prioritized on natural materials without processes, or those that have gone through as little as possible, prioritizing sustainable materials that are produced sustainably, prioritizing all materials, designs, and produced locally. Fifth, processing waste with a separate system and processed on-site, processing organic waste on-site, and recycling non-organic waste with local partners.

Some hotels in Bali have implemented this marketing model but the marketing mix element that is applied is not comprehensive yet, and the application are different from one hotel to another. However, depth interviews with marketers in Bali show their positive attitude towards the 7P + marketing mix as an entity that needs to be applied because it has clear objectives in supporting efforts to realize sustainable tourism in Bali. In practice, at the same time, knowledge, perception, and commitment are needed to gradually integrate the 7P + marketing mix elements. According to the Advisory Board of the Bali Sales \& Marketing Community (BASCOMM), Ms. Fransiska Handoko "Stating that the marketing model used today in Bali, one example is Marketing Mix 7P is still oriented only on the economic side, meaning that the efforts made are still limited to meeting targets or volumes that can be interpreted as simply focused on profit (profit). This will be very detrimental to Bali in the long run. What needs to be done by Bali as a solution in the future is how to balance the achievement of economic, environmental and socio-cultural performance to avoid conditions where future generations experience problems in meeting their future needs" (Source: Depth Interview with Ms. Fransiska Handoko on April 26, 2020)

One example of a tourist area in Bali that has implemented the concept of sustainable tourism is the Sanur area. Sanur Beach is an icon that is famous for its flagship potential in the form of coral reefs. Over time, the arrangement of shade trees along the coast creates a calm and comfortable atmosphere. Adjacent to the beach, the Le Mayeur Museum is also a special attraction for tourists. The historical record displayed by the museum today is very valuable. The role of the Yayasan Pembangunan Sanur plays an important role in anticipating and regulating tourism development in Sanur area (Sudjana et. Al 2019). This is where the local community plays an important role through the Yayasan Pembangunan Sanur not only as a tourism stakeholder but also as a tourism shareholder. 


\section{CONCLUSION AND SUGGESTIONS}

The innovative marketing model is present as a response to the negative impact caused by the marketing model which is currently applied by most types of accommodation businesses in Bali which are more focused on achieving economic aspects. The innovation model is formulated and tested with marketers to be used as marketing solutions in meeting the profit targets set by the company while prioritizing social and environmental aspects so that business continuity can be achieved and aspirations for sustainable tourism can be achieved together. The sustainability marketing innovation model does not make the economic aspect the only indicator of the company's successful performance but also considers the sustainability of social and environmental aspects as an integral and inseparable element in each of its marketing mix strategies. This combination produces a new marketing model called the marketing mix 7P for sustainability or in short is called the Marketing Mix 7P +. The plus sign (+) in this model indicates the concept of sustainability which refers to the achievement of 3P performance (profit, people, and the planet). The 7P + marketing mix consists of; product + , price + , place + , promotion + , participants + , physical evidence + , and process + .

The spirit of the 7P + marketing mix as the first finding is to create sustainable tourism. To achieve this goal, accommodation entrepreneurs in Bali should avoid showing off to make a profit but to realize sustainability. Not because profit is not important, but profit like placed as something that has been achieved or has passed. As with the use of the term postgraduate which characterizes that college students are not looking for formal certificates but knowledge for personal development, post-profit is a marketing paradigm of accommodation services that does not stop to accumulate profits but goes beyond to realize tourism development continuity. In the context of a business mindset, the post-profit paradigm can be explained by the story of The Goose that Laid the Golden Eggs, which has the metaphor that the main goal must be caring for geese if you want to get eggs instead of getting eggs and forgetting the importance of caring for geese.

Suggestions that can be given are: First, marketing practitioners are advised to transform their marketing models and approaches so that their contribution to the development of sustainable tourism in Bali becomes more apparent. The way to do this is by applying the 7P + marketing model and continually adjusting it according to the times, technology, and global conditions that become the arena of tourism activities and the local conditions in which entrepreneurs operate their businesses.

Secondly, it is recommended for the government and the community to closely support and regulate business governance so that business objectives are in line with the 7P + marketing spirit. The role of government is very important, especially in making regulations and managing business records, while the community as a tourism stakeholder can actively support the business climate by preparing citizens to become good human resources so that they have competitive value in entering the tourism economic access. The community is advised to become increasingly aware of their position as a target for welfare in the people category by making the community actively develop regional potential and human resource potential to support sustainable Bali tourism.

Third, for future research, it is recommended to continue the study on the role of marketers in supporting sustainable tourism development in Bali, because the tourism industry is very dynamic and what is considered ideal now may face changes and new challenges in the future to be adjusted. In addition to research with marketers and marketing as study subjects, research on other subjects in the tourism sector also needs to be done in optimizing their role in achieving sustainable tourism development in Bali.

\section{REFERENCES}

1. Akama, J.S and Kieti, D, 2007, "Tourism and Socio-economic Development in Developing Countries: A Case Study of Mombasa Resort in Kenya", Journal of Sustainable Tourism, Vol. 15, No. 6, pp. 735-48. 
2. Ardika, I Wayan. 2007. Pustaka Budaya and Pariwisata. Denpasar:Pustaka Larasan.

3. Bendesa, I Komang Gde and Ni Made Asti Aksari. 2017. "From Agricultural to Tourism Hegemony: A Deep Socio-Economic Structural Transformation" dalam Sylvine PickelChevalier (ed) Tourism in Bali and the Challenge of Sustainable Development, pp. 76102. London: Cambridge Scholars Publishing.

4. Bramwell, Bill, Bernard Lane, Scott McCabe, Jan Mosedale \& CarolineScarles. 2008. "Research Perspectives on Responsible Tourism", Journal Of Sustainable Tourism 16:3, 253-257.

5. Dewi, Ike J. 2011. Implementasi and Implikasi Kelembagaan Pemasaran Pariwisata yang Bertanggung Jawab. Jakarta: Kementrian Kebudayaan and Pariwisata Republik Indonesia.

6. Ghozali, I. and Chariri, A., 2007. Teori Akuntansi. Semarang: Badan Penerbit Universitas Diponegoro.

7. Gurtner, Yetta. 2016. "Returning to paradise: Investigating issues of tourism crisis and disaster recovery on the island of Bali", Journal of Hospitality and Tourism Management, Vol. 28 (2016) 11-19.

8. Jamrozy, Ute. 2007. Marketing of Tourism: A Paradigm Shift Toward Sustainability. International Journal of Culture, Tourism and Hospitality Research. Vol. 1 No. 2, pp. 117 $-130$.

9. Jauhari, Vinnie (ed). 2014. Managing Sustainability in the Hospitality and Tourism Industry: Paradigms and Directions for the Future. Toronto, Kanada: Apple Academic Press, Inc.

10. Jensen and Meckling, 1976. The Theory of the Firm: Manajerial Behaviour, Agency Cost, and Ownership Structure, Journal of Financial and Economics, Vol. 3, pp. 305-360.

11. Picard, M., 2006, Bali Pariwisata Budaya and Budaya Pariwisata, Penerjemah Jean Couteau and Warih Wiratsana, Jakarta: Kepustakaan Populer Gramedia, Forum JakartaParis.

12. Pitana, G., \& Gayatri, P. 2005. Sosiologi Pariwisata Yogyakarta: CV Andi Offset.

13. Pomering, A., Johnson, L., \& Noble, G. 2010. Conceptualising a contemporar y marketing mix for sustainable tourism marketing. Proceedings of the 20th Annual Conference of the Council for Australian University T ourism and Hospitality Education (CAUTHE) (pp. 115). H obart: School of Management, University of Tasmania.

14. Prior, D. et al. 2008. Are Socially Responsible Managers Really Ethical? Exploring the Relationship between Earnings Management and Corporate Social Responsibility. Journal Compilation Vol 16 No 3, May.

15. Putra, I Nyoman Darma and Michael Hitchcock. 2005. "Pura Besakih: A World Heritage Site Contested", Indonesia and the Malay World, Vol. 33, No. 96, pp. 225-238.

16. Putra, I Nyoman Darma and Syamsul Alam Paturusi. 2017. Metamorfosi Pariwisata Bali, Tantangan Memabangun Pariwisata Berkelanjutan. Denpasar: Pustaka Larasan.

17. Rahmawati, Putu Indah, Min Jiang, Alexandra Law, Agung Suryawan Wiranatha \& Terry DeLacy. 2018. "Spirituality and corporate social responsibility: an empirical narrative from the Balinese tourism industry", Journal of Sustainable Tourism, Vol. 27, No. 1, pp. 156172.

18. Sudjana, I Made I Komang Gde Bendesa, Agung Suryawan Wiranatha. 2016. "Sanur Area Development Strategy Towards Green Tourism Destination", Management Studies, Sep.-Oct. 2019, Vol. 7, No. 5, 427-434. doi: 10.17265/2328-2185/2019.05.003. 